PontIFícIA UNIVERSIDADE CATÓLICA dO RIO DE JANEIRO

\title{
Empreendedorismo Feminino Entre Mulheres da Classe C: Estratégias de Superação dos Desafios.
}

Aluane Soares da Silva

Trabalho de Conclusão de Curso

Centro de CIÊNCIAS SOCIAIS - CCS

DePARTAMENTO de AdMINISTRAÇÃo

Graduação em Administração de Empresa 


\section{Empreendedorismo Feminino Entre Mulheres da Classe C: Estratégias de Superação dos Desafios}

Trabalho de Conclusão de Curso

Trabalho de Conclusão de Curso, apresentado ao programa de graduação em Administração da PUC-Rio como requisito parcial para a obtenção do titulo de graduação em Administração.

Orientador(a) : Claudia Duarte Soares

Rio de Janeiro, Dezembro de 2016. 


\section{Agradecimentos}

Dedico este trabalho à minha mãe, pelo apoio, paciência, dedicação e por acreditar no meu sonho, e me ajudar a realizá-lo. Por me tornar a mulher que sou hoje, por ser meu exemplo de vida e ter batalhado anos, para que eu tivesse o melhor que ela pôde me dar. Deixo aqui meu agradecimento aos meus amigos e parentes por me incentivarem e não desistir do meu objetivo.

Agradeço também minha orientadora, Cláudia Soares, que também foi minha professora, pela paciência e incentivo por ter acreditado em mim, no meu potencial, por ter me ajudado nesta jornada e por sua amizade.

Aos meus amigos, que me deram suporte não só durante a construção deste trabalho, mas ao longo do curso e da vida, que sempre estiveram do meu lado principalmente ao Matheus, William, Lília, Maiara, Isabel, Raphaela e Jéssica.

Quero agradecer, em especial, minha avó, Cinyra, falecida esse ano, que não chegou a realizar seu sonho de me ver formada, mas que acreditava que esse sonho se realizaria. Pelo seu exemplo de mulher e por tudo o que representou na minha vida. 


\section{Resumo}

Silva, Aluane. Soares, Cláudia Empreendedorismo Feminino Entre Mulheres da Classe C: Estratégias de Superação dos Desafios. Rio de Janeiro, 2016. Trabalho de Conclusão de Curso - Departamento de Administração. Pontifícia Universidade Católica do Rio de Janeiro.

As empreendedoras da Classe $\mathrm{C}$, que já enfrentam o desafio como preconceitos e estigmas sociais, comum nas favelas, local onde vivem, enfrentam desafios ligados ao gerenciamento de seus negócios. Neste estudo, buscou-se identificar quais são esses desafios, quais fatores que auxiliam sua gestão e quais dificultam, e quais estratégias estas utilizam para superar os desafios enfrentados na gestão de seus empreendimentos.

Palavras- chave

Empreendedorismo feminino. Classe C. Desafios do processo empreendedor.

\section{Abstract}

Silva, Aluane. Soares, Cláudia Empreendedorismo Feminino Entre Mulheres da Classe C: Estratégias de Superação dos Desafios. Rio de Janeiro, 2016. Trabalho de Conclusão de Curso - Departamento de Administração. Pontifícia Universidade Católica do Rio de Janeiro

Women entrepreneurs Class $\mathrm{C}$, which already face the challenge as prejudices and social stigmas, common in the slums where they live, face challenges associated with managing your business. In this study, we sought to identify what are the challenges, what factors help their management and which make it difficult, and what strategies they use to overcome the challenges faced in the management of their enterprises.

Key-words 


\section{Sumário}

1 O tema e o problema de estudo 1

1.1. Introdução ao tema e ao problema do estudo 1

1.2. Objetivo do estudo 3

1.3. Objetivos intermediários do estudo 3

1.4. Delimitação e foco do estudo 3

1.5. Justificativa e relevância do estudo 4

2 Referencial teórico 5

2.1. O empreendedorismo feminino 5

2.2. Classe C 7

2.3. Os desafios do processo empreendedor 11

$\begin{array}{ll}\text { 2.4. Empreendedorismo nas favelas } & 12\end{array}$

3 Métodos e procedimentos de coleta e de análise de dados do estudo 14

3.1. Etapas de coleta de dados 14

3.2. Fontes de informação selecionadas para coleta de dados no estudo15

3.3. Procedimentos e instrumentos de coleta de dados 15

3.3.1. Roteiro das entrevistas 16

3.4. Tratamento e análise dos dados 17

$\begin{array}{ll}\text { 3.5. Limitações do Estudo } & 17\end{array}$

4 Apresentação e análise dos resultados $\quad 19$

$\begin{array}{ll}\text { 4.1. Perfil das empreendedoras } & 19\end{array}$

4.2. Motivação 20

4.3. Principais dificuldades $\quad 21$

4.3.1. Obtenção de capital 22

4.4. Estratégias de superação dos desafios 22

4.5. Fatores facilitadores 23

4.5.1. Iniciativas Governamentais 24 
5 Conclusões e recomendações para novos estudos

6 Referências bibliográficas

Anexo 1

\section{Lista de figuras}

Figura 1: Proporção dos domicílios de Classe C na RMRJ em 2010 .9

\section{Lista de Tabelas}

Tabela 1: Sistema de Pontos CCEB (por posse de itens) .......................

Tabela 2: Sistema de Pontos CCEB (por grau de instrução) ...................7

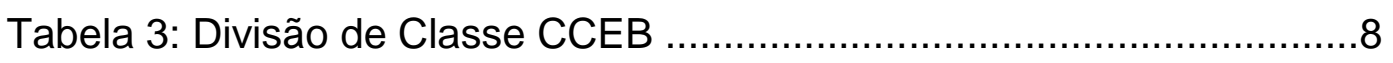

Tabela 4: Perfil das empreendedoras entrevistadas .........................19 


\section{0 tema e o problema de estudo}

\subsection{Introdução ao tema e ao problema do estudo}

No passado, a mulher era totalmente dependente de seu pai, e posteriormente de seu marido, realizando trabalhos estritamente domésticos, inviabilizando e restringindo a mulher a qualquer projeto de profissionalização. Aos poucos as mulheres foram conquistando seu espaço, vencendo as barreiras do papel tradicional de ser apenas mãe, esposa e dona de casa. Hoje, segundo os dados do "International Business Report 2013", da consultoria Grant Thornton, que entrevistou altos executivos de 12,5 mil empresas em 44 países, houve um grande crescimento na ocupação de mulheres em cargos importantes dentro das empresas. Na última década, as mulheres veem conquistando o mercado de trabalho e essa conquista se repete também nas iniciativas empreendedoras. Segundo levantamento do Anuário das Mulheres Empreendedoras e Trabalhadoras (2012) com informações da Pnad, IBGE, no ano de 2012 o Brasil possuia 7,3 milhões de mulheres empreendedoras.

Segundo dados do relatório Global Entrepreneurship Monitor (GEM;2015) no Brasil, quase metade (49\%) dos empreendedores são mulheres. Conforme pesquisa realizada pelo Instituto Data Favela, com o apoio do Instituto Data Popular e da CUFA (Central Única das Favelas), em março de 2015, 40\% dos moradores das favelas brasileiras desejavam ser donos do próprio negócio. Essa porcentagem ultrapassa a média brasileira de $23 \%$, segundo a mesma pesquisa. Entre estes moradores que desejam ter seu próprio negócio, 56\% pertencem à classe $C, 38 \%$ são da classe baixa ( $D$ e E) e $7 \%$ de classe alta (A e B). Desse total, $49 \%$ são homens e $51 \%$ mulheres. Vale ressaltar que esta classificação segue o Critério de Classificação Econômica Brasil (CCEB).

Com um elevado número de favelas no município do Rio de Janeiro surge uma problemática cujo foco central é o crime violento, tendo os traficantes de drogas ilícitas como principais atores.

Em 2008, o então governador do Estado do Rio de Janeiro, Sérgio Cabral, anunciou a criação das Unidades de Polícias Pacificadoras (UPP's) nas 
favelas cariocas, como uma nova solução para a segurança pública. O objetivo consistia na retirada do tráfico, substituindo-o por uma polícia mais próxima dos cidadãos.

Nas favelas pacificadas, que são territórios antes dominados pelo tráfico e que receberam UPP'S, com a finalidade de fortalecer programas sociais nas comunidades antes negligenciadas da cidade, o Sebrae/RJ em parceria com o Rotary Internacional, conta com o projeto Mulher Empreendedora, que é uma plataforma de serviços que visa unir e apoiar as mulheres empreendedoras de todo o país no desenvolvimento de seu negócio. Segundo dados do censo empresarial sobre o perfil de empreendedores em 18 favelas pacificadas, realizado pelo Sebrae/RJ, em 2012, 94\% destes empreendedores eram formados por negros e mulheres que decidiram empreender por necessidade.

De acordo com estudos realizados pelo projeto Mulher Empreendedora, fatores como a necessidade de assumir gastos familiares ou simplesmente 0 sonho de ter o próprio negócio impulsionam mulheres de classes $C, D$ e $E$ a empreender. Grande parte dessas mulheres são responsáveis pelo sustento da casa, de seus filhos e até mesmo de seus netos. Quando decidem empreender e manter esse negócio, seu pensamento é manter por longo tempo esse crescimento social e financeiro, além de investirem em seus estudos e capacitação. A intenção não é somente alavancar financeiramente, mas fazer com que seus resultados alcançados sustentem seu futuro e de sua família.

Segundo SEBRAE/SP 2013, tradicionalmente, as mulheres concentramse em setores onde o faturamento é mais baixo comparando aos rendimentos dos homens, são esses setores, o de vestuário (47\%), produção de artigos diversos como brinquedos e bijuterias (15\%), seguidos pela indústria de alimentos e bebidas (11\%). Mas comércios e serviços concentram a maioria das empreendedoras, 64\%, destacando-se salões de beleza, bares, lanchonetes e ambulantes. Mais de $70 \%$ das donas do negócio faturam até dois salários mínimos. Segundo Luiz Barreto, presidente do SEBRAE, "A criação do Microempreendedor Individual também permitiu a formalização de negócios tocados por mulheres de menor renda, impulsionadas pela ascensão da classe C na última década". O rendimento médio real das mulheres donas de negócio obteve um crescimento de $41 \%$, enquanto o rendimento dos homens cresceu 37\% na última década, entre 2001 e 2011.

Apesar dos indicadores positivos dessas pesquisas, as iniciativas empreendedoras também lidam com as incertezas do ambiente e carecem de profissionalização de gestão. Segundo SEBRAE, o estudo Mulheres 
Empreendedoras no Brasil destaca que empresárias com no mínimo ensino superior incompleto, é quase o dobro de percentual de homens na mesma situação. Dentre as empresárias $18 \%$ cursam a universidade, contra $11 \%$ dos homens.

Assim, em função não só do crescimento das iniciativas empreendedoras femininas, mas também de suas dificuldades, este estudo pretende compreender: Quais são os de desafios enfrentados por mulheres ao empreender?

\subsection{Objetivo do estudo}

O estudo que se segue tem por objetivo identificar os principais desafios enfrentados pelas mulheres da classe $\mathrm{C}$ ao empreender e levantar dados sobre as estratégias utilizadas para a superação desses desafios.

\subsection{Objetivos intermediários do estudo}

Para alcançar o objetivo proposto existem etapas a serem cumpridas. Assim, o trabalho prevê os seguintes objetivos intermediários listados a seguir:

$\checkmark$ Desenvolver um questionário para coleta de dados, e aplicá-lo com a finalidade de identificar as estratégias das mulheres na possível superação de desafios apresentados ao longo de sua trajetória empreendedora.

$\checkmark$ Identificar, através dos dados obtidos, os fatores que facilitam e/ou dificultam o processo empreendedor entre mulheres da classe $\mathrm{C}$.

$\checkmark$ Entender $o$ que as estimulam a empreender, enfrentando os desafios como o de conciliar as funções profissionais e pessoais.

\subsection{Delimitação e foco do estudo}

O presente trabalho está delimitado a mulheres da classe $\mathrm{C}$, moradoras das favelas pacificadas na cidade do Rio de Janeiro, no ano de 2016, que possuem seu próprio negócio.

Este estudo visa apenas levantar os desafios que estas mulheres enfrentam e as ações tomadas para resolução dos possíveis problemas gerados por estes desafios. Não é foco deste trabalho elaborar soluções ou estratégias, 
medir o retorno financeiro, assim como não pretende estabelecer ou sugerir um modelo de gestão.

Vale ressaltar que não é objetivo da pesquisa obter informações sobre faturamento, questões financeiras, ou construção de capital, desta forma sugerese estudos e pesquisas complementares.

\subsection{Justificativa e relevância do estudo}

A relevância do estudo está em contribuir para a exploração do tema que, apesar de sua importância, existem poucos estudos propostos a ele. E analisar e apresentar os principais fatores que estão envolvidos no empreendedorismo entre mulheres de baixa renda com a finalidade de identificar aqueles que possam facilitar e/ou dificultar seu processo empreendedor.

A busca por mais informações, que traduzam o fenômeno do empreendedorismo feminino, os desafios e oportunidades que mulheres da classe $\mathrm{C}$ possuem, impulsionam a realização deste estudo, pois visa incentivar e ampliar o investimento nos estudos acadêmicos neste campo, considerado importante no cenário econômico atual, no qual apresenta grande crescimento.

O estudo é de grande relevância para o autor, pois é capaz de apresentar fatores importantes a cerca destas mulheres à frente de negócios e os desafios enfrentados no seu processo empreendedor.

As informações geradas por este estudo podem ser de grande importância no campo acadêmico, possibilitando um aprofundamento nesta área de estudo, estimulando pesquisadores e alunos no interesse sobre o tema, que ainda apresenta poucas pesquisas. 


\section{Referencial teórico}

Neste capítulo são apresentados e discutidos conceitos, pesquisas relacionadas ao presente trabalho, que servirão de base para as análises realizadas ao final.

Inicialmente, o estudo apresenta uma base sobre o empreendedorismo feminino, em seguida, são apresentados os conceitos da classe na qual as mulheres, foco do estudo, estão inseridas, a Classe C. Após isto, serão discutidos os desafios enfrentados por empreendedores, focando nas mulheres. E por fim, o empreendedorismo nas favelas.

\subsection{0 empreendedorismo feminino}

O O Brasil tem se revelado um país empreendedor, de acordo com estudos realizados pelo GEM (2002), mas infelizmente a falta de levantamentos estatísticos e pesquisas sobre a mulher empreendedora impossibilita o avanço de estudos sobre o tema. Em contrapartida, este fator pode servir como motivação para o surgimento de novas pesquisas sobre o assunto, viabilizando soluções para os problemas existentes tais como a implantação de politicas públicas de apoio ao fomento e desenvolvimento dos negócios geridos por mulheres; disseminação de uma cultura empreendedora; facilitação ao acesso de linhas de crédito e outros problemas pertinentes, que poderiam ser solucionados com mais estudos na área.

Inevitavelmente ao tentarmos compreender o empreendedorismo feminino, é comum fazermos comparações de gênero procurando indicar diferenças entre homens e mulheres em sua forma de gestão. O estudo de Gouvêa, Silveira e Machado (2013) ressalta que homens são mais objetivos, enquanto as mulheres são mais flexíveis e subjetivas. Enquanto os homens centralizam informações e objetivos, as mulheres procuram compartilhá-las. Outra característica marcante é que mulheres conseguem administrar diversos papéis, tornando-as mais versáteis e criativas, porém por outro lado limitam os compromissos que estas possam assumir.

Porém, mesmo com suas limitações, é com essa versatilidade e criatividade que as mulheres, assim como os homens buscam empreender como 
forma de complementar a renda familiar, já que, cada vez mais as mulheres vêm assumindo o sustento familiar, aumentando a participação na economia do país (Meira et. al. 2008). Hoje, as mulheres representam 40,9\% na chefia dos lares brasileiros (IBGE, 2016). Já para Bennett \& Dann, 2000, os motivos estão relacionados ao desejo de realização e identificação de oportunidades de negócios.

Para Silveira (2007) as mulheres acreditam que empreender oferece mais vantagens como mais liberdade, realização, autonomia e independência financeira e satisfação com a atividade empreendedora sobre suas vidas, mesmo enfrentando restrições como tempo de dedicação à família e preocupações com a casa.

Dentre as razões para estas mulheres empreenderem descritas por Machado et. al. (2003) destacam-se realização pessoal; a necessidade de aumentar a renda; a insatisfação no emprego e a impossibilidade de ascender profissionalmente; a necessidade de um horário flexível; o desejo de independência; e, uma maneira de conciliar trabalho e família; Já o relatório OECD (2000) descreve as razões para mulheres empreender e as divide em 3 grupos: empreendedoras por acaso, que são aquelas que empreendem sem antes definir um objetivo, ou ao menos planejar-se, comumente realizam atividades derivadas de um hobby; empreendedoras forçadas, que empreendem devido à alguma circunstância como dificuldade financeira, morte dos pais ou separação; e empreendedoras criadoras que iniciaram seus negócios devido sua própria motivação e coragem, buscando independência e autonomia.

Como bem sabemos, as mulheres exercem múltiplos papéis, Jonathan (2001) observa que as empreendedoras brasileiras buscam intensamente estabelecer um ponto de equilíbrio entre demandas profissionais e pessoais, e só o alcançam quando conseguem perceber que trabalho e família se ajudam mutualmente. Por outro lado, os índices de satisfação das empreendedoras do nosso país estão ligados ao trabalho, filhos e respeito próprio, indicando que os espaços pessoal, familiar e profissional, contribuem equilibradamente para o bem-estar psicológico destas mulheres (Jonathan, 2005).

Há evidências de que as mulheres encaram desvantagens no campo do empreendedorismo em função do gênero. As mulheres comumente são vítimas de estereótipos de inferioridade em relação ao sexo masculino, e enfrentam dificuldades quanto ao acesso de recursos financeiros (Cassol, 2006). A produção de estereótipos construiu-se ao longo do tempo com o padrão de dominação masculina, contribuindo para que as mulheres sejam vistas como 
frágeis e submissas ao homem. Beauvoir (2009) aponta que esta dominação se manifesta na posição secundária da mulher em nossa sociedade. Quanto à obtenção de recursos financeiros, Korhonen (2000) enfatiza que os bancos privilegiam empresas criadas e dirigidas por homens.

\subsection{Classe C}

O Critério de Classificação Econômica Brasil (CCEB), divide a população em cinco classes, sendo elas $A, B, C, D$ e E, baseando-se em características como a posse de bens, o nível de instrução do chefe de família e a existência de empregados mensalistas no domicilio para estimar o poder de compra de domicílios. Esta classe representa hoje mais de $52 \%$ da população brasileira (CPS-FGV, 2012).

A classificação de classe social de acordo com o CCEB divide as classes econômicas por um sistema de pontos, como mostrado nas tabelas 1 e 2 . Esta classificação visa estimar o poder de compra das pessoas e famílias urbanas, abordando de uma forma diferente a chamada "classe social".

Tabela 1 - Sistema de Pontos CCEB (por posse de itens)

\section{Posse de itens}

\begin{tabular}{l|c|c|c|c|c|}
\hline \multirow{2}{*}{} & \multicolumn{5}{|c|}{ Quantidade de Itens } \\
\cline { 2 - 6 } & 0 & 1 & 2 & 3 & 4 ou + \\
\hline Televisão em cores & 0 & 1 & 2 & 3 & 4 \\
\hline Rádio & 0 & 1 & 2 & 3 & 4 \\
\hline Banheiro & 0 & 4 & 5 & 6 & 7 \\
\hline Automóvel & 0 & 4 & 7 & 9 & 9 \\
\hline Empregada mensalista & 0 & 3 & 4 & 4 & 4 \\
\hline Máquina de lavar & 0 & 2 & 2 & 2 & 2 \\
\hline Videocassete e/ou DVD & 0 & 2 & 2 & 2 & 2 \\
\hline Geladeira & 0 & 4 & 4 & 4 & 4 \\
\hline $\begin{array}{l}\text { Freezer (aparelho independente } \\
\text { ou parte da geladeira duplex) }\end{array}$ & 0 & 2 & 2 & 2 & 2 \\
\hline
\end{tabular}

Fonte: ABEP - Associação Brasileira de Empresas de Pesquisa - 2008

\section{Tabela 2 - Sistema de Pontos CCEB (por grau de instrução)}

\section{Grau de Instrucão do chefe de familia}

\begin{tabular}{|l|l|c|}
\hline Analfabeto / Primário incompleto & Analfabeto / Até 3 3 $^{\text {. Série Fundamental }}$ & 0 \\
\hline Primário completo / Ginasial incompleto & Até 4 ${ }^{\mathrm{a}}$. Série Fundamental & 1 \\
\hline Ginasial completo / Colegial incompleto & Fundamental completo & 2 \\
\hline Colegial completo / Superior incompleto & Médio completo & 4 \\
\hline Superior completo & Superior completo & 8 \\
\hline
\end{tabular}

Fonte: ABEP - Associação Brasileira de Empresas de Pesquisa - 2008 
$\mathrm{Na}$ tabela 3, contabiliza-se pontos conforme posse de itens e o grau de instrução do chefe de família, definindo as classes econômicas (A1, A2, B1, B2, C1, C2, D e E) conforme a soma destes. O principal objetivo do CCEB é mensurar a classe social não apenas pela renda, mas considera também o nível de conforto e escolaridade.

\section{Tabela 3 - Divisão de Classe CCEB}

\begin{tabular}{|c|c|c|}
\hline Classe & TONAL BRASIL & $\begin{array}{c}\text { TOTA } \\
(\%)\end{array}$ \\
\hline A1 & $42-46$ & $0,9 \%$ \\
\hline A2 & $35-41$ & $4,1 \%$ \\
\hline B1 & $29-34$ & $8,9 \%$ \\
\hline B2 & $23-28$ & $15,7 \%$ \\
\hline C1 & $18-22$ & $20,7 \%$ \\
\hline C2 & $14-17$ & $21,8 \%$ \\
\hline D & $8-13$ & $25,4 \%$ \\
\hline E & $0-7$ & $2,6 \%$ \\
\hline
\end{tabular}

Fonte: ABEP - Associação Brasileira de Empresas de Pesquisa - 2008

De acordo com o Censo Demográfico IBGE 2010, das 338 áreas que compõem a Região Metropolitana do Rio de Janeiro (RMRJ) 171, ou seja, um pouco mais da metade, representam domicílios da classe $\mathrm{C}$. $\mathrm{Na}$ cidade do Rio de Janeiro essa representação é superior a 50\%. A região central (Centro e Santa Teresa) apresenta maior predominância de residentes da Classe C alcançando 60\% dos domicílios. No subúrbio (Madureira, Penha, Ramos, Inhaúma, Irajá, Méier) e Zona Oeste (Jacarepaguá, Bangu, Campo Grande) os índices são superiores a 50\% como mostrado no gráfico. Estes índices elevados devem-se pela concentração de grandes favelas nestas áreas. Conforme apresentado na figura1. 


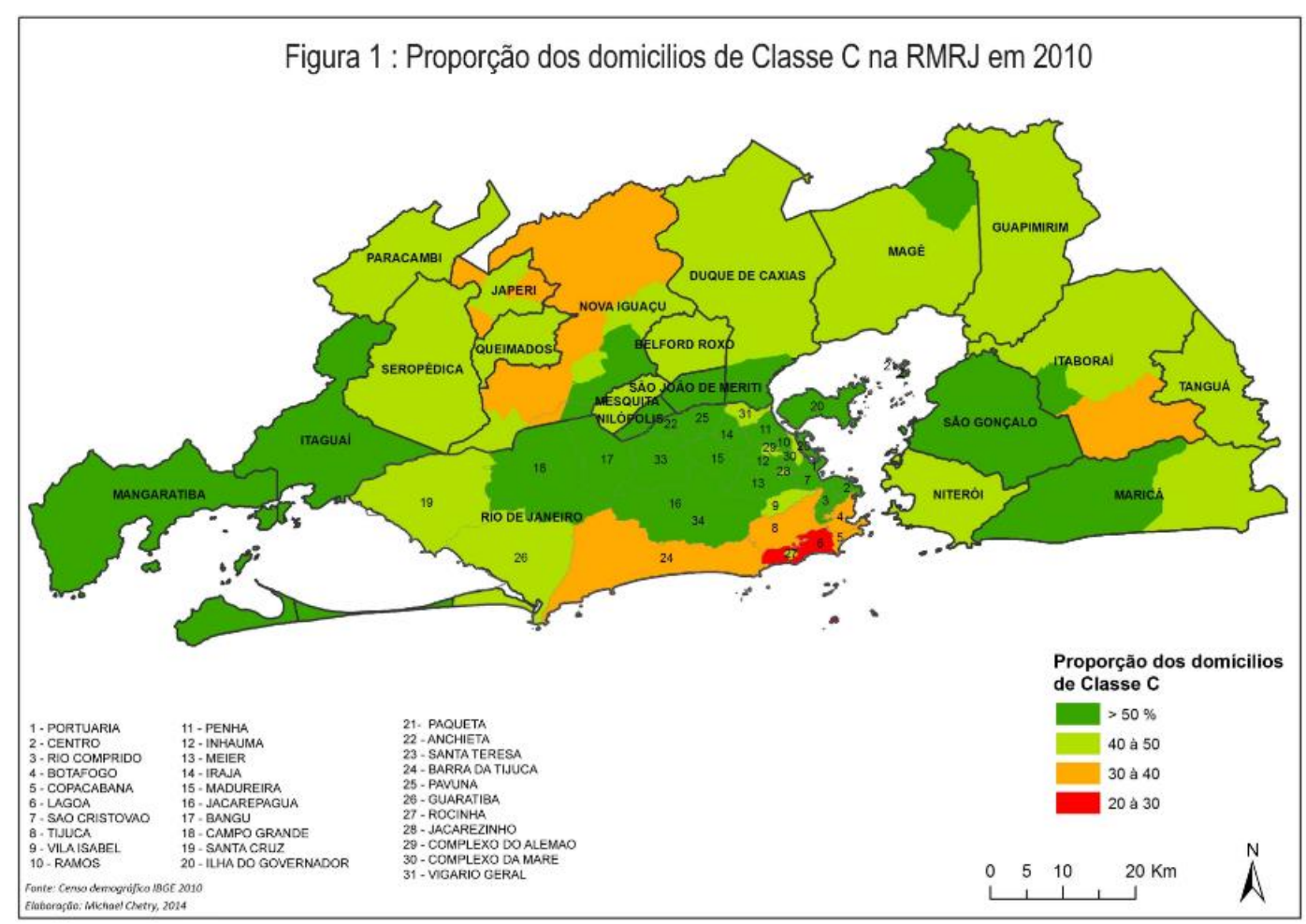

Fonte: Censo Demográfico IBGE 2010

Classificando-as por renda mensal, Neri (2008) define famílias de classe média como aquelas que possuem faixa mensal entre $R \$ 1.064$ e $R \$ 4.591$. As classes $A$ e $B$ com renda superior a $R \$ 4.591$, enquanto a classe $D$, ganha entre $R \$ 768$ e $R \$ 1.064$. E por sua vez, a Classe $E$ reúne famílias com rendimentos abaixo de $\mathrm{R} \$ 768$.

Quanto aos gastos, segundo o instituto Kantar Wordpane, a classe C gasta mais do que ganha, apresentando um déficit de $2 \%$. Somente a Classe $\mathrm{C}$, dentre as cinco classes, apresenta esse déficit (Moreira, 2012). Para Barros e Rocha (2007) o crédito surge como a melhor opção para a Classe C, pois possibilita que participem da sociedade de consumo que desejam. E ainda, através do parcelamento conseguem realizar várias compras ao mesmo tempo.

$\mathrm{Na}$ década de 2000 houve um aumento significativo da representatividade da Classe $\mathrm{C}$ no mercado brasileiro devido a alguns fatores, propiciando a ascensão desta classe no mercado consumidor. Medeiros (2008) destaca que os fatores são os estímulos governamentais e as iniciativas privadas para viabilizar o consumo de novos segmentos da população. A facilidade do acesso à informação, concessões de crédito ao consumidor e a criação do Código de Defesa do Consumidor fizeram com que este consumidor se posicionasse no mercado e obtivesse destaque diante das empresas, que voltaram sua atenção a este novo segmento. 
Hoje com a atual recessão econômica, houve uma reconfiguração no consumo e na expansão da Classe $\mathrm{C}$ no Brasil. Com altas taxas de desemprego, estagnação e alta inflação esta classe apresenta alto grau de endividamento. Levantamentos do SCPC Boa Vista aponta que 60\% dos 57 milhões de inadimplentes no Brasil pertencem a Classe $\mathrm{C}$, dentro desse total, a principal causa do endividamento é o desemprego (35\%) e o descontrole financeiro (29\%). Com o aumento do desemprego, cresce o número de pessoas que desejam abrir seu próprio negócio, esse fenômeno é chamado de "empreendedorismo por necessidade". Dados da PNAD revelam que entre abril de 2014 e janeiro de 2016 o número de pessoas trabalhando por conta própria subiu de 20,8 milhões para 23 milhões, aumentando em 10,5\%.

O Instituto Pereira Passos (IPP) e o Censo 2010 revelam que 20\% dos habitantes da cidade do Rio de Janeiro residem em favelas, onde há maior concentração desta classe social. O crescimento das favelas no Brasil, que se fez visível a partir de 1980, está associada à fatores como o alto índice de desemprego, crescimento da informalidade, especulação imobiliária, falta de política habitacional para a população mais pobre e sistema de transporte público precário, especificamente no município do Rio de Janeiro.

O aumento dos crimes e violência no município do Rio de Janeiro tornouse o principal problema urbano. Tipificadas como território de violência da cidade, as favelas passaram a ser o principal foco na implantação de políticas e práticas estatais visando à segurança pública. De acordo com o Censo 2010, no município do Rio de Janeiro, 38 UPP's foram instaladas até hoje. Este dispositivo atinge 264 das 1.071 localidades, representando apenas $25 \%$ das favelas cariocas.

Pesquisas sobre as UPP's (CEVIS, 2012, 2011; CANO, 2012; BURGOS et al, 2011; CUNHA e MELLO, 2011) afirmam que a percepção dos moradores quanto a melhora na qualidade de vida e a sensação de paz nas favelas após a chegada das UPP's, propagou-se na comunidade. Houve redução do risco de morte por parte dos tiroteios gerados por confrontos entre polícia e traficantes. Cano (2012) considera que após a ocupação da Polícia Pacificadora e seu período de vigência, reduziu consideravelmente os homicídios praticados por policiais, o que é reconhecido pelos moradores ouvidos na pesquisa. Porém, as pesquisas também mostram que há persistência das práticas policiais abusivas e violentas, tais como violência física, assédio sexual, revistas vexatórias, entre outras. Além disso, moradores queixam-se quanto à falta de segurança dentro 
das favelas, que deveria ser realizada pelas UPP's. São recorrentes denúncias de relatos de estupro e roubo que não são apurados, por exemplo.

Além dessas questões, a política de pacificação da favela e o campo de requalificação do trabalho informal como empreendedorismo vêm ganhando destaque, pois redefine as possibilidades de inclusão social de moradores de favelas no Rio de Janeiro.

\subsection{Os desafios do processo empreendedor}

Muitas são as dificuldades enfrentadas por empreendedores. No Brasil, dados levantados pelo SEBRAE (2000), ressaltam fatores como alta carga tributária e a falta de capital de giro como principais fatores que dificultam a gestão de pequenos negócios. Já quanto ao empreendedorismo feminino, Gomes (2004) destaca a dificuldade de conciliar trabalho e família.

O papel tradicional da mulher do ponto de vista da sociedade é baseado no de mãe e cuidadora principal, isto gera aspectos negativos como sentimento de culpa e estresse dentro das relações sociais. Mcgowan, Redeker, Cooper e Greenan (2012) averiguaram em sua pesquisa que para muitas mulheres gerar seu próprio negócio proporciona maior liberdade e flexibilidade, ao mesmo tempo em que gera insatisfação quando não conseguem equilibrar as exigências do negócio e os interesses da família. Complementar a esta questão, o estudo de Buttner e Moore (1997) ressalta a influência da família na decisão de empreender como um dos fatores mais citados. Ao mesmo tempo em que a família tona-se importante no processo empreendedor é vista também como um fator que dificulta esse processo. Porto (2002) em sua pesquisa destaca que as empreendedoras sofrem o peso da reação dos maridos e homens próximos, pelo ciúme, inveja e rivalidade.

Os principais desafios enfrentados por mulheres como empreendedoras, apresentadas por Gomes, Santana e Silva (2005), são: dificuldades de autoconceito e aceitação; falta de suporte efetivo e social; dificuldades para atuar no mercado internacional; dificuldade de financiamento; dificuldade de acesso a redes (networks) e falta de mentores; tamanho das empresas; falta de tempo; dificuldade em conciliar trabalho e família; dilema entre obrigação e desejo; ausência de modelos de referência de empreendedoras.

Para Nogueira, Alvarez e Urbano (2013) os fatores socioculturais que mais influenciam as empreendedoras são o medo de fracassar e a percepção de capacidade em gerir o negócio. É possível entender esse conceito se 
considerarmos que as mulheres enfrentam dificuldades como a falta de experiência, medo do risco financeiro e de dívidas, falta de modelos e o baixo nível de assistência.

Machado et al (2003) verificou que as empreendedoras brasileiras, constituem sua fonte de capital inicial com recursos provenientes de economias pessoais ou empréstimos de familiares e amigos. De acordo com Filion citado no relatório GEM (2010), 25\% das mulheres acreditam que são tratadas diferentes pelas instituições financeiras. Uma das causas da inviabilidade de empréstimos em bancos é a dependência financeira das mulheres para com seus maridos ou outras figuras masculinas, precisando assim do aval destes para viabilizar o financiamento.

Um estudo realizado por Carter, Willians e Reynolds (1997), mostrou que mulheres possuem maior dificuldade de obtenção de recursos financeiros, principalmente de modo formal. Outra pesquisa, adicional a esta, realizada por Machado et al (2010) comparou a obtenção de recursos financeiros por homens e mulheres para criar seus negócios e destacou que independente do gênero, a principal fonte foi economia pessoal. As diferenças entre gêneros aparecem quando se trata de questão de recursos de terceiros. A pesquisa aponta que $13,9 \%$ dos homens mencionaram empréstimos informais contra 6,3\% das mulheres. Quanto aos recursos de terceiros formais 7\% dos homens 0 mencionam, enquanto nenhuma das mulheres o cita.

\subsection{Empreendedorismo nas favelas}

Segundo uma pesquisa realizada em 2015, pelo $2^{\circ}$ Fórum Nova Favela Brasileira, realizado pela parceria entre o Instituto Data Popular e a CUFA Central Única das Favelas, o poder de consumo nas favelas aumentou juntamente com o interesse dos moradores de empreender. De um total de 3,8 milhões de brasileiros que desejam empreender nas favelas brasileiras 53\% são mulheres. Para dar inicio a esses novos empreendimentos, as iniciativas mais citadas foram: começar a economizar dinheiro (30\%), trabalhar no planejamento do negócio (28\%), procurar equipamento ou local (25\%) e buscar recursos de terceiros (19\%). E entre os motivos estão listados: "não ter chefe" (29\%), ter fonte de renda (22\%) e poder ganhar mais (20\%).

Meirelles (2014) conclui que as áreas hoje pacificadas perderam capital de investimento do tráfico, que aumentava o volume de dinheiro circulante na favela. Segundo o autor, membros das organizações compravam no comércio 
local, patrocinavam eventos e muitas vezes praticavam algum assistencialismo. Sem o comércio das drogas, o Estado vê-se desafiado a substituir esse poderoso motor econômico.

A principal dificuldade nas favelas pacificadas é diminuir o número do trabalho informal, pois falta informação a estes empreendedores, afirma Carla Teixeira, coordenadora de empreendedorismo em comunidades pacificadas do SEBRAE/RJ. Ainda segundo o SEBRAE/RJ, em 2011 cerca de 1.700 negócios foram formalizados, principalmente nas áreas de alimentação, beleza e comercio varejista. Porém dados da entidade revelam que 92\% dos negócios na favela não são regularizados. Ferreira (2012) Rocha, Schmid e Ramalho (2013) destacam que após a implantação das Unidades de Polícia Pacificadora houve um aumento significativo de empreendedorismo formal.

Iniciativas nas favelas têm sido criadas para legalizar e estimular o empreendedorismo. Como por exemplo, o Microempreendedor Individual (MEI), criado em 2009 pelo SEBRAE, formalizando empreendedores com faturamento bruto anual de até 60 mil reais; A Favela Holding, que é um tipo de sociedade entre empresas, apresentando oportunidade de negócios direcionados para favela, seja na produção de empregos ou estímulo ao empreendedorismo; e o projeto mulher empreendedora, que é uma iniciativa do SEBRA/RJ e o Rotary Internacional, que fomentam o empreendedorismo feminino nas favelas através da geração de renda familiar e o resgate da autoestima.

O perfil do empreendedor nas favelas pacificadas é formado em sua maioria por mulher que atuam por conta própria (94\%); idade média de 43 anos; com baixa escolaridade, média de 7 anos de estudo e trabalham com comércio ou prestação de serviços (ABEND, 2014, pg.39). 


\section{Métodos e procedimentos de coleta e de análise de dados do estudo}

Este capítulo pretende informar sobre as diversas decisões acerca da forma como este estudo será realizado.

Está dividido em cinco seções que informam sobre as etapas de coleta de dados do estudo realizado, as fontes de informação selecionadas para a coleta de informações neste estudo, os processos e instrumentos de coletas de dados realizados em cada etapa, com respectivas justificativas, as formas acolhidas para tratar e analisar os dados coletados e, por fim, as possíveis repercussões que as decisões sobre como realizar o estudo impuseram os resultados assim obtidos.

\subsection{Etapas de coleta de dados}

Esta pesquisa foi conduzida com o intuito de entender quais as facilidades e dificuldades enfrentadas no processo empreendedor de mulheres da classe C. Para isso foi preciso entender, primeiro, o empreendedorismo feminino no Brasil, suas características e seus desafios e segundo, 0 ambiente em que os empreendimentos destas mulheres estão inseridos.

Desta forma, a natureza desse estudo é qualitativa. Segundo Minayo (1998) as pesquisas qualitativas penetram no universo dos comportamentos, atitudes e valores implícitos ao objeto e ao contexto pesquisado, buscando o significado de variáveis que não podem ser reduzidas à quantificação. Em outras palavras, os estudos realizados de forma qualitativa respondem a questões muito particulares, preocupando-se com o nível de realidade que não pode ser quantificado.

O método de pesquisa utilizado é o exploratório. Para Gil (2010) este tipo de pesquisa tem o intuito de desmistificar o problema a ser estudado e construir hipóteses, permitindo uma maior compreensão do assunto e oferecendo flexibilidade na sua realização. Esse tipo de pesquisa não requer tanto planejamento, envolvendo levantamento bibliográfico e documental, entrevistas não padronizadas e estudos de caso. 
O trabalho contou com duas etapas de coletas de dados. A primeira etapa foi a coleta de dados secundários através da pesquisa bibliográfica, onde foram levantados artigos e livros relacionados aos temas em questão. A segunda etapa foi a pesquisa de campo realizada por meio de entrevistas, onde foram coletados dados primários a partir da resposta de mulheres empreendedoras moradoras de favelas pacificadas.

\subsection{Fontes de informação selecionadas para coleta de dados no estudo}

O trabalho contou com dados secundários oriundos de artigos acadêmicos, dissertações e artigos de revista. Essas fontes foram pesquisadas na biblioteca da Pontifícia Universidade Católica do Rio de Janeiro e em suas bases de dados, em páginas da internet como, Estadão, Sebrae e Valor Econômico, Associação Nacional de Pós-Graduação e Pesquisa em Administração (ANPAD), Scientific Periodics Eletronic Library (SPELL), entre outros que auxiliaram na procura de informações relevantes para este trabalho.

Outro método utilizado para coletar dados foi o de entrevistas individuais que contaram com o auxílio de um roteiro semiestruturado. Foram entrevistadas mulheres moradoras das favelas Santa Marta, Cidade de Deus e Rocinha, hoje pacificadas. Os locais foram escolhidos não só porque hoje contam com as instalações de UPP's, mas também por terem sido indicados por amigos, sendo, desta forma, mais acessíveis à pesquisadora. Foram selecionadas seis mulheres que possuem empresas nessas localidades, número considerado satisfatório para uma pesquisa qualitativa, visando uma análise mais profunda dos dados. $\mathrm{O}$ contato foi feito por telefone e agendado de acordo com a disponibilidade das entrevistadas.

\subsection{Procedimentos e instrumentos de coleta de dados}

O procedimento adotado foi a entrevista. Para Gil (2011), a entrevista é uma forma de diálogo assimétrico, no qual uma das partes busca coletar dados e a outra se apresenta como fonte de informação. Dentre os tipos de entrevista, foi escolhida a entrevista individual, muito utilizada em estudos exploratórios como esse, pois tem o propósito de proporcionar melhor compreensão do problema, gerar hipóteses e fornecer elementos para a construção de instrumentos de coleta de dados. Além disso, permite investigar um tema em profundidade.

:As entrevistas em profundidade foram realizadas no ambiente profissional dos entrevistados após prévia autorização por contato telefônico por parte do 
entrevistador, informando que se tratava de uma pesquisa acadêmica para o trabalho de conclusão de curso. Todas as entrevistas ocorreram durante o horário comercial.

As questões eram abertas e roteirizadas de forma semiestruturada e foram realizadas em outubro de 2016. As entrevistas procuraram levantar, de acordo com a percepção dos respondentes, questões como os fatores que facilitam/dificultam a gestão de seu negócio e a identificação de estratégias para a superação de desafios enfrentados por elas.

Além disso, antes de iniciar as entrevistas foi informado aos entrevistados que o conteúdo era confidencial e seria utilizado apenas para fins acadêmicos.

Apresenta-se, a seguir, o roteiro das entrevistas.

\subsubsection{Roteiro das entrevistas}

\section{Perfil do Entrevistado}

Nome (não será divulgado):

Idade:

Estado civil:

Caso possua filho (s), favor informar a(s) idade(s):

Escolaridade:

Nome da empresa

Segmento da empresa

Ano de criação da empresa

\section{Roteiro de Entrevista}

1) O que levou você a abrir o seu próprio negócio?

2) Quais foram as principais dificuldades enfrentadas para abrir o negócio?

3) Quais os fatores que ajudaram você a vencer as dificuldades de empreender?

4) Como você conseguiu capital para abrir sua empresa?

5) Quais são os principais desafios que você enfrenta hoje na gestão do seu negócio?

6) De que forma você busca superar esses desafios?

7) Quais são os fatores que facilitam/favorecem a sua gestão? 
8) Você conta com o apoio de alguma inciativa governamental? Em caso afirmativo, qual e de quem?

\subsection{Tratamento e análise dos dados}

Os dados foram analisados através da técnica de análise de conteúdo, que segundo Vergara (2005), tem o objetivo de detectar o que está sendo dito sobre um determinado assunto, podendo assim, assimilar as informações e comparálas.

Bardin (1977,p.42) define a análise de conteúdo como sendo: "um conjunto de técnicas de análise das comunicações visando obter, por procedimentos sistemáticos e objetivos de descrição do conteúdo das mensagens, indicadores (quantitativos ou não) que permitam a inferência de conhecimentos relativos as condições de produção/recepção(variáveis inferidas) destas mensagens". Resumindo, é uma técnica usada para identificar o que está sendo dito a respeito de determinado tema.

Neste estudo, primeiramente as entrevistas foram gravadas e depois transcritas. Em seguida, foram definidas as unidades de análise, que podem ser: palavra, expressão, frase, parágrafo. Nesse caso, foram usadas as frases e parágrafos.

Por fim, na última etapa, o conteúdo extraído das entrevistas foi comparado com o referencial teórico. Essa técnica é chamada de emparelhamento (associação dos resultados ao referencial teórico). Assim sendo, coube ao pesquisador concluir a pesquisa e elaborar o relatório retornando as suposições/hipóteses formuladas e confirmá-las ou não com as devidas explicações.

\subsection{Limitações do Estudo}

Os métodos escolhidos para a coleta de dados têm suas vantagens e desvantagens. Primeiro, a entrevista permite a obtenção de dados em profundidade. Além disso, oferece flexibilidade, isto é, permite o entrevistador esclarecer o significado das perguntas e adaptarem-se mais facilmente às pessoas e às circunstâncias em que se desenvolve a entrevista. Por outro lado, a falta de motivação do entrevistado para responder as perguntas que the são 
feitas pode ser um problema. Além disso, o pesquisador precisa manter a empatia durante o processo.

O método qualitativo, baseado em entrevistas de profundidade, não permite a generalização para o público-alvo. A realização da pesquisa com mulheres de diferentes idades apresenta o risco de percepções distintas referente ao problema estudado.

A veracidade do conteúdo exposto pelo sujeito é limitador, tendo em vista que não se pode comprovar que as perguntas tenham sido respondidas de retratando, realmente sua opinião acerca do estudo. Deste modo, a escolha de realizar a pesquisa no ambiente profissional, deixando-as mais confortáveis, foi uma forma de tentar minimizar este problema.

Em contrapartida, muitos dados secundários são reportados de forma equivocada, o que pode comprometer a pesquisa. Para não reportar esse erro, é importante que a fonte desses dados seja analisada em profundidade, evitando essas incoerências e/ou contradições.

Já a limitação da entrevista é o vício do autor que apesar da intenção de se manter imparcial ou neutro na interpretação dos dados coletados, ele pode influenciar o entrevistado através do seu aspecto pessoal, assim como também pode deixar transparecer suas opiniões e percepções pessoais sobre as respostas dos entrevistados. 


\section{Apresentação e análise dos resultados}

Este capítulo apresenta e discute os principais resultados alcançados e suas implicações.

Está organizado em cinco seções. A primeira apresenta o perfil das empreendedoras de Classe $C$, a segunda suas motivações para empreender, a terceira as principais dificuldades enfrentadas em seu processo empreendedor, a quarta apresenta as estratégias de superação de desafios, e por último, os fatores facilitadores em sua gestão.

\subsection{Perfil das empreendedoras}

As entrevistadas estão na faixa média de idade de 38 anos, possuindo a mais jovem a idade de 24 anos e a mais velha 50 anos. Quanto ao nível de escolaridade, três delas, completaram o ensino médio, ou seja, possuem pelo menos 12 anos de estudo. A que apresentou o nível mais baixo de escolaridade, ensino fundamental, representa 9 anos de estudo e as outras duas de nível de escolaridade superior, graduação, representa 16 anos de estudo. A Tabela 4 sintetiza o perfil.

Tabela 4 - Perfil das empreendedoras entrevistadas

\begin{tabular}{|c|c|c|c|c|c|c|c|}
\hline & \multicolumn{3}{|c|}{ Idade Estado Civil Filhos } & Escolaridade & Nome da empresa & Segmento & Ano de Criação \\
\hline E1 & 39 & \begin{tabular}{|l|l|} 
Casada \\
\end{tabular} & 3 & Ensino médio completo & lís Decor & Decoracção de festas infantis & 2014 \\
\hline E2 & 30 & Solteira & 0 & Graduada em moda & Passarela Carioca & Moda & 2015 \\
\hline E3 & 50 & Casada & 4 & Ensino médio completo & Loja da Mave & Vare & 1993 \\
\hline E4 & 36 & \begin{tabular}{|l|} 
Divorciada \\
\end{tabular} & 1 & Gaduada em essética & Beauly & Serviços Pessoal & 2014 \\
\hline E5 & 24 & União Estável| & 0 & Ensino médio completo & Saläo de beleza Contraste & Serviços Pessoais & 2011 \\
\hline E6 & 49 & Divoriada & 3 & Ensino fundamental completo & Quentinhas da tia Silvia & Alimentação & 2006 \\
\hline
\end{tabular}

Fonte: Elaborado pela autora, 2016

Quanto ao segmento de atuação profissional, divide-se entre comércio e prestação de serviços. E1 do segmento de decoração de festas infantis, possui 
uma loja de festas infantis localizada na Cidade de Deus, apesar de trabalhar somente com decoração, sua sócia atua com buffet. E2, do segmento de moda possui uma loja de roupas na Santa Marta. E3 possui uma loja, onde vende desde roupas infantis até materiais escolares, localizada na Cidade de Deus. As entrevistadas do segmento de serviços pessoais, E4 e E5, possuem um salão de beleza, uma na Santa Marta e outra na Rocinha. E, por fim, E5 possui uma lanchonete que prepara comidas para viagem, pratos feitos, lanches e bebidas na Rocinha.

Os dados apresentados pela pesquisa possuem semelhanças com os apresentados por ABEND (2014), como quando destaca que as empreendedoras das favelas pacificadas trabalham com comércio ou prestação de serviços. Porém, quando se trata da média de idade e anos de estudo, o autor destaca a idade de 43 anos e 7 anos de estudo.

\subsection{Motivação}

Inicialmente, a pesquisa buscou entender quais os motivos que levaram as mulheres a empreender.

Quando indagadas sobre os motivos que as conduziram a abrir seu próprio negócio, as repostas dividiram-se, e surgiram fatores como a identificação de oportunidades de negócios, confirmando os estudos de Bennett \& Dann (2000). A insatisfação no emprego, a impossibilidade de ascender profissionalmente, a necessidade de um horário flexível, uma maneira de conciliar trabalho e família e a necessidade de aumentar a renda, citadas por Machado et. al. (2003). Como ilustrada o comentário a seguir:

"A gente trabalhando para outras pessoas o tratamento é totalmente diferente, e a gente trabalhando pra gente é melhor. Tenho mais tempo pra mim e pro meu filho também, aqui faço meu horário" E4

A vontade de "não ter mais chefe" também aparece como uma motivação das empreendedoras entrevistadas. Assim como apresentado na pesquisa realizada pelo $2^{\circ}$ Fórum Nova Favela Brasileira, em parceria com o Instituto Data Popular e a CUFA, no ano de 2015.

Observa-se ainda que as entrevistadas estejam, em sua maioria, classificadas como empreendedoras por acaso (OECD 2000), pois não definiram um objetivo e não se planejaram. 


\subsection{Principais dificuldades}

A principal dificuldade citada no processo de abertura das empresas foi a obtenção de recursos financeiros, como verificado por Machado et. Al. (2003) e confirmado na pesquisa de Carter, Willians e Reynolds (2007).

“(...)A falta de dinheiro, no caso." E1

"A principio eu senti dificuldade financeira(...)."E5

"A dificuldade foi conseguir capital(...)" E6

A inexperiência e o medo de arriscar financeiramente também foram citados pelas entrevistadas. Atestando os estudos de Nogueira, Alvarez e Urbano (2013). A entrevistada E2 menciona, que mesmo com a experiência anterior no setor em que seu empreendimento atua não a ajudou a sanar duvidas iniciais, como por exemplo, o processo de compras:

“(...)por mais que eu tenha trabalhado lá, eu consegui fornecedor, entendia os processos, mas eu nunca tive de fato uma loja minha. Perguntas como onde compra? fiquei perdida! Tem que ter blusa, tem que ter saia, mas quanto de cada coisa? Porque na teoria é lindo, fácil, mas na prática, meu bem, é outra coisa(....)." E2

A pesquisa também identificou elementos como conciliar família e trabalho, destacado por Gomes (2004). E3 precisou do auxílio de sua mãe para conseguir conciliar as demandas profissionais com os pessoais.

"Na época meus filhos ainda eram pequenos e minha mãe me ajudava, assim, olhava eles, né?" E3

A parte burocrática, que envolve o processo de formalização de Micro empresas, o chamado MEI do SEBRAE, foi citado como uma dificuldade no processo de empreender pela entrevistada E2. 
“(..)A parte burocrática também, cheguei a fazer uns cursos no SEBRAE, antes de abrir a loja, mas já pensando na parte de gestão, essa foi a parte que eu menos gostei, a mais chata" E2

Hoje, a principal dificuldade enfrentada na gestão de seus negócios, é a concorrência, segundo a visão de todas as entrevistadas. A crise também foi considerada por algumas entrevistadas, como um fator dificultador.

E2 colocou como dificuldade o fato de sua loja estar limitada à favela. Ela acredita que teria maior visibilidade, se estivesse em uma rua de maior movimentação, como ela mesma mencionou, a São Clemente.

\subsubsection{Obtenção de capital}

Os dados obtidos nesta pesquisa corroboram com o de Machado et. al. (2003), relatando que as empreendedoras obtêm seu capital inicial através de economias pessoais, ou empréstimos de familiares e amigos. Apenas E6 citou empréstimo em instituição financeira, mas utilizando a ajuda de seu chefe, como recurso para a obtenção do financiamento.

\subsection{Estratégias de superação dos desafios}

As estratégias utilizadas pelas entrevistadas envolvem, em sua maioria, driblar a concorrência utilizando meios e ferramentas criativas e buscando diversificar ou diferenciar seus produtos.

E6 relata que seu diferencial está na adaptação de seus produtos a demanda atual, ela busca na diversificação um método de driblar as dificuldades que enfrenta com relação à concorrência.

"Ah, eu tenho meu diferencial né? Procuro trabalhar com alimentos diferenciados como comidas mais saudáveis que as pessoas estão procurando mais agora, faço salgados, vendo pastéis, empadão, faço até suco verde." E6

Entre as ferramentas que as auxiliam na busca por clientes, E2 citou redes sociais, como instragram e facebook, considerando-as como uma forma "ser vista", em suas palavras. Utilizando-se de sua criatividade conta com suas amigas como modelos para expor seus produtos. Ainda, utilizou-se de sua rede de relacionamentos para obter vantagem competitiva, como o marketing espontâneo da atriz Roberta Rodrigues no seu empreendimento. 
Um fato interessante é que as entrevistadas do segmento de serviços pessoais, ambas possuem um salão de beleza, utilizam as mesmas estratégias como promoções e brindes.

E1 considerou curso de especialização como estratégia para superar seus desafios, apesar de considerar a internet uma ferramenta importante para diferenciar-se da concorrência.

\subsection{Fatores facilitadores}

Um dos fatores facilitadores citados foi o apoio de amigos, que promoveu a divulgação do seu negócio e possibilitou a conquista de novos clientes. Como apresentada por E1.

"Geralmente eu monto as festas dos meus amigos, e eles acabam me indicando pra outros amigos chego a fazer 10 festas por mês só por indicação dos meus amigos."E1

O apoio e envolvimento da família no negócio foi citado por três das entrevistadas. Este envolvimento se dá desde o processo de produção, como relata a entrevistada do setor de alimentos, até o auxílio na venda de seus produtos e na gestão do negócio como relata E3.

"Meus filhos ficam na loja nos dias de que eu tenho que ir pra feira, e meu marido me ajuda também." E3

E3 citou a experiência anterior como um facilitador no início do processo empreendedor, segundo ela, manusear o caixa e a forma de tratamento no atendimento ao cliente, ajudou-a. Mas, além disso, ela buscou não limitar-se apenas ao seu empreendimento, buscando expor seus produtos em feiras realizadas dentro e fora da favela onde vive.

Não pagar aluguel, e com isso ter um gasto a menos, e ainda ter continuado a trabalhar, foi considerado por E5 como um fator importante para a realização do seu negócio. 


\subsubsection{Iniciativas Governamentais}

Das seis entrevistadas, apenas E2 e E5 são $\mathrm{MEI}$, e das quatro que não são apenas E3 tem o interesse de formalizar seu negócio pelo projeto apresentado do SEBRAE/RJ.

"Não! Mas já tenho conhecimento do MEI, que eu sei que posso até ter CNPJ, mas por enquanto não tenho vontade não, só mais pra frente" E3

E6 considera o processo de formalização complicado, já tentou, mas não obteve sucesso. Este fato pode estar ligado à dificuldade do SEBRAE/RJ em formalizar os empreendimentos nas favelas pacificadas juntamente com a falta de comunicação com as empreendedoras. 


\section{Conclusões e recomendações para novos estudos}

O objetivo proposto neste trabalho foi alcançado, uma vez que foram evidenciados os desafios enfrentados pelas empreendedoras de Classe $\mathrm{C}$ e as estratégias utilizadas para superar esses desafios.

Entre aos desafios citados na fase inicial de seus empreendimentos estão a obtenção de capital financeiro e a vontade de não trabalhar mais para terceiros. O apoio da família e o uso das redes de relacionamento foram algumas das ferramentas utilizadas para a resolução destes problemas, além da utilização de suas economias pessoais.

Outros desafios foram identificados como o medo de se arriscar, a dificuldade em conciliar família e trabalho, a concorrência e a dificuldade de expandir seus negócios para fora da favela.

Com o estudo foi possível entender que as estratégias utilizadas evidenciam inovação, criando arranjos alternativos para os desafios que enfrentam, o que produz mudanças tanto no contexto profissional quanto no pessoal.

Uma dificuldade apontada pela investigação foi a barreira emocional da mulher, ligado ao processo de acreditar que é possível. Algumas entrevistadas não abandonaram seus empregos, não somente por não obter renda suficiente em seus empreendimentos a ponto de conseguir sustentar-se, mas também por não acreditar que o sonho de ter seu próprio negócio fosse possível.

O problema maior gerado por essa barreira é quando a mulher passa a associar suas dificuldades à falta de competência. A falta de competência encontrada nas entrevistas está relacionada à gestão financeira de seus negócios, algumas das entrevistadas revelaram estar inseguras quanto a isso, mas não as impediu de começar ou ir à diante com seus empreendimentos. Além disso, em nossa cultura, a mulher ainda se sente inferior ao homem profissionalmente, e a desigualdade salarial tanto de gênero quanto de raça persiste. Se por um lado este fato corrobora para este sentimento, por outro impulsiona o empreendedorismo feminino, principalmente entre as mulheres da classe C. 
Como solução para combater a desigualdade de gênero, o empoderamento feminino tem como sua principal marca a conquista de espaço no mercado de trabalho. No empreendedorismo destacam-se a inovação, o espírito de liderança e a habilidade para crescer e mudar sua própria realidade. A partir desse movimento, hoje é possível perceber que nossa sociedade está aprendendo a reconhecer o papel da mulher como agente do desenvolvimento econômico, social e cultural. Mas ainda há muito que fazer, as barreiras que impedem o crescimento profissional e pessoal das mulheres não estão presentes apenas no meio profissional, mas na sociedade que ainda insiste em restringi-las aos papeis tradicionais.

O empoderamento feminino que hoje permeia a sociedade está associado como um fator que favorece o empreendedorismo feminino, pois é uma forma da mulher se valorizar e mostrar a força que tem. A questão de empreender por necessidade agora está dando lugar à vontade, ao desejo e a auto realização. Hoje, é comum encontrar mulheres que empreenderam por escolha e não por questões financeiras, como visto também nos resultados apurados neste trabalho.

É interessante observar que as entrevistadas estão buscando por especialização, e almejam se desenvolver profissionalmente através de cursos profissionalizantes. Outro fato interessante é o desejo de empreender em sua área de estudo, mais evidente nas entrevistadas que possuem empreendimentos mais recentes como as entrevistadas do segmento de moda e de serviços pessoais, formadas em moda e estética respectivamente.

A substituição de necessidade por vocação pode estar ligada à facilidade de acesso da classe $\mathrm{C}$ aos cursos de graduação, técnicos e profissionalizantes nos últimos anos. Esse ponto favorece na escolha dessas mulheres se arriscarem mais em um setor que já possuem algum conhecimento, proporcionando a busca por oportunidade ao empreender e um alto grau de identidade com a atividade profissional.

O medo de arriscar entre as empreendedoras não está ligado apenas a questões financeiras, mas também se sentem inseguras em arriscar em algo novo, e sair de sua zona de conforto, fato identificado também nesse estudo. Porém, o medo de arriscar tem seu lado positivo, que traz como consequência maior planejamento e cautela ao investir em algum empreendimento.

O conflito trabalho-família não representou, neste trabalho, um fator que dificulte o processo empreendedor como apresentado por Buttner e Moore (1997), mas um importante elemento na decisão de empreender. 
Em resumo, muitas características das empreendedoras vêm sendo modificadas, como o aumento de anos de estudo, a busca por aperfeiçoamento, e a forma de gestão criativa e dinâmica, que não só facilitam o processo de empreender, mas também as tornam mais seguras e competentes frente a seus negócios.

Apesar de pertencerem a classe $\mathrm{C}$, morarem em favelas, e serem vistas como aquelas que historicamente foram fragilizadas por atitudes preconceituosas e ações discriminatórias da sociedade, essas mulheres desempenham um papel que vai além da conquista de seu empreendimento, demonstram que são capazes de superar não somente os desafios de gestão, mas também as dificuldades impostas pela realidade em que vivem.

A construção deste trabalho foi inspirada em mulheres reais, presentes na vida da autora. A realização deste estudo proporcionou um melhor entendimento, e, além disso, aprofundou conhecimentos específicos que mais tarde poderão ser úteis para o desenvolvimento de mecanismos e novos estudos que possibilitem essas mulheres aprimorarem sua gestão.

Por fim, recomenda-se que pesquisas sejam realizadas e continuadas nesta área não só avaliando a participação de mulheres como gestoras, mas também o impacto econômico e social de seus empreendimentos dentro das favelas. Além disso, também é interessante investigar o quanto a ausência e a permanência dos projetos de pacificação em favelas impactam nos negócios dessas empreendedoras. Recomenda-se ainda compreender as motivações que levam as mulheres a investirem em prestação de serviços e comercio. 


\section{Referências bibliográficas}

ALPERSTEDT, G.; FERREIRA, J. ; SERAFIM, M.; Empreendedorismo Feminino: dificuldades relatadas em histórias de vida. Revista de Ciências da Administração, v. 16, p. 221-234, 2014.

ARCOVERDE, L. Cresce o numero de mulheres em cargos de liderança. $O$ Valor, São Paulo 2013. Disponível em:< http://www.valor.com.br/carreira/3157310/cresce-o-numero-de-mulheres-emcargos-de-lideranca >Acesso em: 20 de julho de 2016.

Associação Brasileira de Empresas de Pesquisa. Critério de classificação econômica Brasil. São Paulo, 2008. Disponível em: 〈http://www.abep.org/> Acessado em: 30 de setembro de 2016.

BARBOSA, M. Maioria dos moradores de favela pretende abrir um negócio em três anos. UOL, São Paulo, 2015. Disponível em: < http://www1.folha.uol.com.br/mercado/2015/03/1597127-maioria-dos-moradoresde-favelas-pretende-abrir-um-negocio-em-tres-anos.shtml > Acesso em: 20 de julho de 2016.

BARDIN, L. Análise de Conteúdo. São Paulo: Edições 70, 1977.

BOMFIM, L. C.; TEIXEIRA, R.; Empreendedorismo Feminino: Desafios Enfrentados por Empreendedoras na Gestão de Pequenos Negócios no Setor de Turismo. Revista Pensamento Contemporâneo em Administração, v. 10, n.2, p. 48-69, 2015.

CALDAS, C. Crise econômica: Entenda a ascensão e a queda da Classe C no Brasil. ZH, São Paulo, 2016. Disponível em: < http://zh.clicrbs.com.br/rs/vidae-estilo/noticia/2016/05/crise-economica-entenda-a-ascensao-e-a-queda-daclasse-c-no-brasil-5795332.html> Acesso:5 de outubro de 2016.

GIL, A. Como elaborar projetos de pesquisa. São Paulo: Atlas, 2010.

GIL, A. Métodos e técnicas de pesquisa social. São Paulo: Atlas, 2008.

GOMES, A. F. O perfil empreendedor de mulheres que conduzem seu próprio negócio: um estudo na cidade de Vitória da Conquista. Revista Alcance Itajaí, v. 11, n. 2, p. 207-226, 2004.

GOMES, A. F., SANTANA, P. G., \& SILVA, M. J.; Mulheres empreendedoras desafios e competências. Revista Técnica Administrativa, vol. 4, n. 24, 2005.

GOMES, M.; et. al. Empreendedorismo Feminino como Tema de Pesquisa. Revista Brasileira de Gestão de Negócios, vol.16, n. 51, p. 319-352, 2014. 
FERREIRA, A. Moradores de favelas pacificadas do Rio viram empresários. UOL, 4 de julho de 2012. Disponível em: < http://economia.uol.com.br/noticias/redacao/2012/07/04/pacificacao-de-favelascariocas-abreportas-para-o-empreendedorismo.htm>. Acesso em: 7 outubro de 2016.

FERREIRA, Á. Favelas no Rio de Janeiro: nascimento, expansão, remoção e, agora, exclusão através de muros. Revista Bibliográfica de Geografía y Ciencias Sociales, Barcelona: Ed. da Universidad de Barcelona, v. 14, n. 828, 2009. Disponível em: <http://www.ub.es/geocrit/b3w-828.htm>. Acesso em: 5 de Outubro de 2016.

FERREIRA, J.; SILVA E. E.; Mulheres e Suas Histórias: Razão, Sensibilidade e Subjetividade no Empreendedorismo Feminino. ANPAD; v. 17, n. 4, p. 398-417, 2013.

JONATHAN, E. G. Mulheres empreendedoras: medos, conquistas e qualidade de vida. Psicologia em Estudo, v. 10, n. 3, p. 373-382, 2005.

LEITE M.; Entre a 'guerra' e a 'paz': Unidades de Polícia Pacificadora e gestão dos territórios de favela no Rio de Janeiro. Revista de Estudos de Conflito e Controle Social, v. 7, n. 4, p. 625-642, 2014.

MEIRELLES, R., ATHAYDE, C. Um país chamado favela. São Paulo: Gente, 2014.

NERI, M. A Nova Classe Média. Rio de Janeiro: CPS, 2008. Disponível em: < http://www.cps.fgv.br/ibrecps/M3/M3 TextoFinal.pdf> Acesso em: 5 de outubro de 2016.

NERI, M. De volta ao País do Futuro: Crise Europeia, Projeções e a Nova Classe Média. Rio de Janeiro: FGV/CPS, 2012. Disponível em: < http://www.cps.fgv.br/cps/bd/ncm2014/NCM2014_TextoCompleto_Fim_texto.pd f> Acesso em: 24 de outubro de 2016.

SANCHES, F.; et. al. Empreendedorismo Feminino: um Estudo Sobre Sua Representatividade no Município de Toledo - Paraná. Revista de Gestão e Secretariado. v. 4, n. 2, p. 134-150, 2013.

Serviço Brasileiro de Apoio às Micros e Pequenas Empresas. Empreendedorismo Feminino Avança na Última Década. São Paulo, 2013. Disponível em:< $\quad$ http://www.sebraesp.com.br/index.php/42noticias/empreendedorismo/8584-empreendedorismo-feminino-avanca-na-ultimadecada >. Acesso em: 20 e julho 2016.

Serviço Brasileiro de Apoio às Micros e Pequenas Empresas. Empreendedorismo Feminino nas Favelas. Rio de Janeiro, 2013. Disponível em:< http://www.rj.agenciasebrae.com.br/sites/asn/uf/RJ/empreendedorismo- 
feminino-nas-favelas,86b53aded3439410VgnVCM1000003b74010aRCRD>. Acesso em: 20 de julho 2016.

Serviço Brasileiro de Apoio às Micro e Socioeconômicos [responsável pela elaboração da pesquisa, dos textos, tabelas e gráficos]. Anuário das mulheres empreendedoras e trabalhadoras em micro e pequenas empresas : 2015, 3.ed., Brasília, DF : DIEESE, 2015. Disponível em: $<$ http://www.bibliotecas.sebrae.com.br/chronus/ARQUIVOS_CHRONUS/bds/bds .nsf/cd949ce3599faa1e095bea15e2ac8ba5/\$File/5861.pdf> Acesso: 20 de julho de 2016.

SILVA J., O Bibliotecário e o Empreendedorismo: Indicações Sobre a Sua Participação no Programa de Desenvolvimento do Empreendedorismo em Comunidades Pacificadas; Rio de Janeiro, 2015, 51p. Trabalho de Conclusão de Curso apresentado à Escola de Biblioteconomia da Universidade Federal do Estado do Rio de Janeiro.

SILVEIRA, A.; GOUVEIA, A. B.; Empreendedorismo Feminino: Mulheres Gerentes de Empresas. Revista da Face, v. 7, n. 3 , p. 124-138, 2008.

THOMÉ, C. IBGE: mulher contribui com $40,9 \%$ da renda familiar. São Paulo, 2014. Disponível em: < http://economia.estadao.com.br/hoticias/geral,ibgemulher-contribui-com-40-9-da-renda-familiar, $1586071>$ Acesso em: 28 de agosto de 2016.

TOMMAS, L. Juventude, Projetos Sociais, Empreendedorismo e Criatividade: Dispositivos, Artefatos e Agentes Para o Governo da População Jovem. Revista Internacional de historia política e Cultura Jurídica, v. 6, n.2, p. 287-311, 2014.

VERGARA, S. Métodos de Pesquisa em Administração. São Paulo: Atlas, 2005.

WAKAI, A. Pesquisa revela dados sobre empreendedorismo nas favelas. Rio de Janeiro, 2015.2 Disponível em: < https://www.ecommercebrasil.com.br/eblog/2015/03/03/pesquisa-revela-dadossobre-empreendedorismo-nas-favelas/ >Acesso: 20 de setembro de 2016.

WINKLER, A.C., MEDEIROS, J., Dificuldades do Papel Empreendedor Desempenhado por Mulheres; Rio de Janeiro, 2011. Caderno de Administração - Universidade Estadual de Maringá- Centro de Ciências Sociais Aplicadas- Departamento de Administração. 


\section{Anexo 1}

\section{E1}

39 anos, Casada, possui 3 filhos (21 anos, 14 anos e 5 anos), completou o ensino médio, atua no segmento de decoração de festas infantis, o nome de sua empresa é Íris Decor, e o ano de criação da empresa é 2014.

9) O que levou você a abrir o seu próprio negócio?

"Foi até uma amiga minha, eu não estava pensando em fazer essas coisas não, mas minha amiga me chamou pra ser sócia com ela porque ela já fazia bolo, né? Bolo, docinho, essas coisas, aí me chamou pra montar festa com ela, como ela não podia porque estava sempre fazendo bolo, doce aí eu entrei de sócia com ela. Então a gente juntou dinheiro e compramos os primeiros móveis."

10) Quais foram as principais dificuldades enfrentadas para abrir o negócio?

"O preço das coisas, né? Os móveis são bem caros! A falta de dinheiro, no caso."

11) Quais os fatores que ajudaram você a vencer as dificuldades de empreender?

"Eu pedi dinheiro emprestado para um amigo, depois fui pagando ele aos poucos."

12) Como você conseguiu capital para abrir sua empresa?

A entrevistada listou como um dos fatores que a ajudaram a vencer as dificuldades a obtenção de capital.

13) Quais são os principais desafios que você enfrenta hoje na gestão do seu negócio?

"Ah, minha filha, a concorrência! Porque muita gente faz decoração também, as coloca o preço lá em baixo, aí acaba desvalorizando o seu trabalho"

14) De que forma você busca superar esses desafios? 
"Ah, inovando as coisas, procurando na internet novas decorações, porque o certo mesmo é você fazer um cursinho, né? Por isso tenho vontade de fazer uns cursinhos pra melhorar."

15) Quais são os fatores que facilitam/favorecem a sua gestão?

"Geralmente eu monto as festas dos meus amigos, e eles acabam me indicando pra outros amigos, chego a fazer 10 festas por mês só por indicação dos meus amigos."

16) Você conta com o apoio de alguma inciativa governamental? Em caso afirmativo, qual e de quem?

"Não!"

\section{E2}

30 anos, solteira, não possui filhos, graduada em moda e cursa pedagogia, o nome de sua empresa é Passarela Carioca, atua no segmento de moda, e o ano de criação da empresa é 2015.

1) O que levou você a abrir o seu próprio negócio?

"Então, eu fiz a loucura de fazer faculdade de moda, né? E aí, assim pra pobre é muito complicado. Eu sempre gostei dessa área, mas eu nunca tive uma referência próxima de mim. Aí teve uma época da minha vida que eu fiz um projeto social que eu fazia teatro, dança, música, e aí lá eu sempre me vi no meio dos figurinos, nessa parte de criação, e tive contato com pessoas desse meio e foi o que me despertou o interesse por moda e aí eu pensei: é isso que eu vou fazer! Após fazer a faculdade, eu não consegui oportunidades para me inserir no mercado de trabalho porque na minha área você tinha que conhecer alguém que já estava dentro da empresa, ou tinha que ser parente de alguém. Todas as minhas amigas estavam se empregando, algumas estavam indo pra fora do país e eu percebi que tinha que fazer alguma coisa. Mas eu cheguei a trabalhar em alguns lugares, depois de muito esforço, só que além de pagar muito mal, eles exigiam um mega currículo, além de um processo seletivo muito chato, graduação, inglês, mas o salário não compensava, era horrível, e eu pensava: nossa, me matei de estudar, fiz cursos, pra ganhar aquilo? O salário era o mesmo que ganhava uma pessoa de serviços gerais, era muito baixo, no final do mês depois de vários descontos só me restavam 900 reais, e não dava pra sobreviver com 
isso. Eu até apostei por um tempo, me dediquei, trabalhava com a expectativa de crescer na empresa, mas eu vi que infelizmente a área está muito saturada. Mas essa minha última experiência me abriu os olhos, porque eles não produzem, não fabricam as roupas, eles apenas revende, tudo made in China, e lá apesar de ser um lugar complicado de trabalhar eu aprendi muito, eu aproveitei o lado positivo e trouxe coisas que aprendi lá pra cá (para o empreendimento). Lá, eu fazia tudo, desde a compra, e-commerce, fazia a arte para o site, quando faltava modelo eu substituía, aprendi um pouco de todos os setores. O dono fazia questão que conhecêssemos todos os setores da loja. Daí que deu um estalo e surgiu a questão: por que eu estou trabalhando tão bem pra eles e não faço isso pra mim? Eu estava me matando de trabalhar, indo pra um lugar longe, meu trabalho não era valorizado, e no setor da moda tem muito preconceito, as pessoas gostam de humilhar as outras pessoas, graças a Deus nunca fui humilhada, mas vi muitas pessoas sofrendo algum tipo de humilhação, enfim, eu não gostava dessa situação, estava me sentindo saturada disso tudo. Então tomei coragem, pedi demissão. Aqui(onde hoje é a loja), funcionava um barzinho e eu sempre ficava de olho nesse lugar, porque não é nem dentro do morro e também não é na rua, porque eu queria pegar o público das pessoas da comunidade, mas eu também queria que pessoas de fora viessem comprar na minha loja, porque dentro do morro já é mais complicado a pessoa pode pensar: ah, como eu vou fazer pra subir, ou então quando o bondinho não estivesse funcionando eu não queria ter essa limitação. Fiquei sabendo que o dono do bar tinha um contrato de 5 anos e pensei que isso nunca iria rolar, os donos eram um casal e o casal brigou e resolveram quebrar o contrato, aí vi uma oportunidade ai e perguntei pra minha mãe: o que a senhora acha? Ela disse que se é o que você quer, se você acha que vai dar certo então vamos. Eu sempre tive muito medo de arriscar, nunca tinha pedido demissão de nada na minha vida, ralei pra caramba pra conseguir trabalhar numa empresa grande, principalmente porque o processo seletivo de lá foi complicado. $E$ arriscar, foi assim, muito difícil pra mim. Então, resolvi abrir a loja pela necessidade de mostrar mais o meu trabalho, de ganhar mais, colocar em prática tudo que eu aprendi na faculdade. " 
2) Quais foram as principais dificuldades enfrentadas para abrir o negócio?

"A primeira foi a questão de achar o lugar ideal e depois foi a adaptação mesmo, por mais que eu tenha trabalhado lá , eu consegui fornecedor, entendia os processos, mas eu nunca tive de fato uma loja minha. Perguntas como onde compra? fiquei perdida! Tem que ter blusa, tem que ter saia, mas quanto de cada coisa? Porque na teoria é lindo, fácil, mas na prática, meu bem, é outra coisa .Uma das dificuldades foi também reformar o bar, porque eu queria abrir uma loja dentro da favela, mas tinha que ser algo bonito dentro das minhas possibilidades. A parte burocrática também, cheguei a fazer uns cursos no SEBRAE, antes de abrir a loja, mas já pensando na parte de gestão, essa foi a parte que eu menos gostei, a mais chata"

3) Quais os fatores que ajudaram você a vencer as dificuldades de empreender?

"Eu liguei pra uma amiga que tem uma loja em Nilópolis e pedi ajuda pra saber como fazia. Então, ela foi muito legal. Ela me levou em alguns fornecedores e me orientou como eu tinha que fazer as coisas, e minha mãe, há muito tempo atrás, foi gerente de loja , então ela tem noção, principalmente da parte financeira que eu acho muito chato, coisas como o CNPJ, isso tudo é com ela! $E$ foi então que minha mãe entrou comigo como sócia, ela já estava aposentada e ela viu que era um sonho meu e ai falou então tá, vou nessa contigo. O apoio da minha família também foi muito importante pra mim, porque eu sou muito medrosa, tive muito medo de arriscar e trocar o certo pelo duvidoso"

4) Como você conseguiu capital para abrir sua empresa?

"Então a minha mãe entrou comigo com uma parte do dinheiro e eu sempre fui muito organizada financeiramente, sempre guardei dinheiro, mesmo ganhando pouquinho, eu guardava."

5) Quais são os principais desafios que você enfrenta hoje na gestão do seu negócio?

"Então, eu tenho muitos desafios, primeiro é porque eu estou no pé da comunidade e ao mesmo tempo em que passa muitos moradores, eu fico um pouco limitada, apesar de ser meio morro, meio rua, eu acho que se minha loja fosse ali na São Clemente, eu ia ter mais visibilidade, eu tenho esse desafio de ser vista. Eu também tenho 
concorrência, apesar de não ter muita loja, aqui tem duas meninas da comunidade antigas, que eram sacoleiras, mas é uma concorrência saudável. Mas não deixa de ser um desafio, porque a gente trabalha com o mesmo público, por exemplo, no natal do ano passado, as pessoas estão acostumadas a sempre comprar com elas, aí apareceu um terceiro elemento, que fui eu, e comecei a pensar como é que eu posso aparecer em uma coisa que já tinha e uma das minhas apostas foi de fazer uma loja bonita. Mas o principal desafio é a crise, porque quando eu abri a loja, foi muito bacana, financeiramente falando. No primeiro dia da loja eu vendi muito, peguei minhas amigas e coloquei elas com uns balões, entreguei panfletos e subi com elas pelo morro chamando as pessoas, também mandei mensagem pra muita gente que eu conhecia e também que eu não conhecia, até mesmo para artistas, ate aquela atriz, a Roberta Rodrigues do Nós do Morro apareceu aqui, sorte do primeiro dia , e na época ela estava em uma novela, e eu achei bacana porque ela é engajada com essa parada de comunidade, então isso fez com que as pessoas viessem aqui na loja e deu super certo no início, mas depois eu senti as pessoas, de maneira geral, não estão gastando tanto com roupa e está tudo muito caro. E eu percebi que até os meus fornecedores, por exemplo, uma roupa que eu comprava por um valor e agora tá mais caro e eu sou obrigada a passar mais caro para o meu cliente, estou tendo que buscar fornecedores mais em conta, mas com a mesma qualidade, porque as outras lojas daqui nem sempre têm essa preocupação com a qualidade, as vezes tem uma roupa legal, mas o acabamento é ruim, a roupa encolhe, então eu tento buscar esse equilíbrio. E o meu desafio é como fazer com que as pessoas comprem nesse momento que ninguém está gastando."

6) De que forma você busca superar esses desafios?

"Eu invisto nas redes sociais, instagram, facebook, fico tentando aparecer né. As vezes eu até vendo o mesmo produto das minhas concorrentes, mas eu procuro mostrar de uma maneira diferente, eu tento fazer o mais próximo possível do que eu fazia na empresa que eu trabalhava. Não tenho modelos profissionais, mas eu tenho algumas amigas bonitas, tiro umas fotos legais, dou uma valorizada na roupa e vi que as pessoas sentem mais prazer em comprar, 
porque viram nas modelos. Esse é o meu diferencial. E também quando alguma menina compra aqui, comprou um look, ai eu digo posta o look e coloca \#passarelacarioca que eu coloco sua foto lá na página, aí a amiga viu, curtiu, pergunta onde você comprou aquele look? Acaba curtindo a página e me ajuda a ter visibilidade"

7) Quais são os fatores que facilitam/favorecem a sua gestão?

"A ajuda da minha mãe, porque eu não tenho como ter funcionário, então é muito complicado, porque eu sou a vendedora, a menina da faxina, sou a office girl, e se não fosse o apoio da minha mãe eu não iria conseguir porque é muita coisa, aí ela toma conta da parte financeira, de colocar preço, se não fosse assim, se não tivesse alguém pra dividir iria ser muito difícil, meu sonho é conseguir contratar uma pessoa pra me ajudar."

8) Você conta com o apoio de alguma inciativa governamental? Em caso afirmativo, qual e de quem?

"Eu sou MEl."

\section{E3}

50 anos, casada, possui 4 filhos (26anos, 23 anos, 19 anos, 15 anos), completou o ensino médio, o nome da sua empresa é Loja da Mave, atua no segmento de varejo, o ano de criação da empresa é 1993.

1) O que levou você a abrir o seu próprio negócio?

"Não querer mais trabalhar fora."

2) Quais foram as principais dificuldades enfrentadas para abrir o negócio?

"Na época meus filhos ainda eram pequenos e minha mãe me ajudava, assim, olhava eles, né?"

3) Quais os fatores que ajudaram você a vencer as dificuldades de empreender?

"Quando eu comecei, já tinha trabalhado muitos anos em uma padaria, então isso me ajudou um pouco, porque eu já tinha noção de caixa, como atender as pessoas, essas coisas. E as vendas por fora, em feiras também."

4) Como você conseguiu capital para abrir sua empresa?

"Eu trabalhava em uma empresa, e quando eu recebi a rescisão eu decidi abrir a loja, e eu também guardava dinheiro. $E$ também uma 
amiga entrou com dinheiro, abriu a loja comigo, mas depois cada uma seguiu seu caminho."

5) Quais são os principais desafios que você enfrenta hoje na gestão do seu negócio?

"hoje? Muita concorrência "

6) De que forma você busca superar esses desafios?

"Procurando criar alguma coisa nova, tentar fazer a diferença."

7) Quais são os fatores que facilitam/favorecem a sua gestão?

"Meus filhos ficam na loja nos dias de que eu tenho que ir pra feira, e meu marido me ajuda também."

8) Você conta com o apoio de alguma inciativa governamental? Em caso afirmativo, qual e de quem?

"Não!"

\section{E4}

36 anos, divorciada, possui um filho de 16 anos, graduada em estética, o nome da empresa é Beauty, atua no segmento de serviços pessoais , o ano de criação de sua empresa é 2014.

1) O que levou você a abrir o seu próprio negócio?

"A gente trabalhando para outras pessoas o tratamento é totalmente diferente, e a gente trabalhando pra gente é melhor. Tenho mais tempo pra mim e pro meu filho também, aqui faço meu horário"

2) Quais foram as principais dificuldades enfrentadas para abrir 0 negócio?

"No início é bem parado, mas depois pelo boca a boca eu fiquei conhecida na favela."

3) Quais os fatores que ajudaram você a vencer as dificuldades de empreender?

"Eu acho que foi a paciência."

4) Como você conseguiu capital para abrir sua empresa?

"Pelo tempo que eu trabalhei, o dinheiro que eu juntei, eu fui montando pouco a pouco."

5) Quais são os principais desafios que você enfrenta hoje na gestão do seu negócio? 
"Acho que foi mais a crise, que atingiu todo mundo, que esta sendo pra mim, uma dificuldade muito grande, porque depois que veio a crise as clientes quase não aparecem mais"

6) De que forma você busca superar esses desafios?

"Bom, eu tento de alguma maneira trazer o cliente, fazendo promoções, por exemplo, dando brindes."

7) Quais são os fatores que facilitam/favorecem a sua gestão?

"Acho que a forma com que eu trato minhas clientes, como me relaciono com elas."

8) Você conta com o apoio de alguma inciativa governamental? Em caso afirmativo, qual e de quem?

"Não! Mas já tenho conhecimento do MEI, que eu sei que posso até ter CNPJ, mas por enquanto não tenho vontade não, só mais pra frente"

\section{E5}

24 anos, em uma união estável, não possui filhos, completou o ensino médio, atua no segmento de serviços pessoais, o nome da empresa é Salão de beleza Contraste, e o ano de criação é 2011

1) O que levou você a abrir o seu próprio negócio?

“Então, eu terminei o ensino médio e eu não sabia qual faculdade fazer, tinha muita dúvida, não sabia o que eu queria. Então fiz um curso técnico de patologia, quase terminei, mas vi que não era isso que eu queria. Aí eu tentei fazer um curso de cabeleireira, porque eu sempre gostei, e falei: vamos ver se me dou bem, aí comecei o curso e me realizei ali, e fui fazendo vários cursos na área, e vi que já estava pronta pra abrir meu negócio"

2) Quais foram as principais dificuldades enfrentadas para abrir o negócio?

"A principio eu senti dificuldade financeira, porque pra abrir um negócio você precisa de uma renda pra poder investir, alugar um lugar, comprar material e tudo isso tem muito gasto, essa renda inicial eu tive um pouco de dificuldade." 
3) Quais os fatores que ajudaram você a vencer as dificuldades de empreender?

"Eu tive ajuda da minha mãe e do meu namorado na época. E como minha mãe me deu uma parte da casa dela pra fazer o salão, eu já não precisava pagar aluguel, o que me ajudou muito porque quando se paga o aluguel, fazendo cabelo ou não tem que pagar o aluguel e isso acaba atrapalhando, e apesar de ter conseguido abrir o salão eu continuei trabalhando na creche, e falei pra mim que só iria sair da creche quando eu tivesse ganhando o mesmo que na creche, e quando comecei a ganhar o mesmo que lá, na verdade ganhava até mais, aí eu sai da creche, porque já tinha minhas clientes fixas, e ganhando mais fiquei só com o salão"

4) Como você conseguiu capital para abrir sua empresa? "Com o trabalho na creche e a ajuda da minha mãe."

5) Quais são os principais desafios que você enfrenta hoje na gestão do seu negócio?

"Hoje é só a crise, antes o fluxo era maior, mas diminuiu um pouco porque as pessoas estão sem dinheiro, mas não foi tão drástico assim, não achei que fosse me afetar, mas está até tranquilo, antes as clientes pagavam muito com dinheiro e agora elas querem comprar mais com cartão e parcelar."

6) De que forma você busca superar esses desafios? "Fazendo promoções e tentando inovar pra chamar mais a clientela, dou desconto também, se for a vista, dou brindes, se fizerem vários procedimentos, essas coisas."

7) Quais são os fatores que facilitam/favorecem a sua gestão? "A questão de não pagar aluguel, isso facilita pra mim, menos um gasto que eu tenho."

8) Você conta com o apoio de alguma inciativa governamental? Em caso afirmativo, qual e de quem?

"Sim, eu sou MEI, sou cadastrada pelo SEBRAE."

\section{E6}

49 anos, divorciada, possui 3 filhos (33 anos, 24 anos e 11 anos), completou o ensino fundamental, atua no segmento de alimentos, o 
nome de sua empresa é Quentinhas da tia Silvia, e o ano de criação é 2006.

1) O que levou você a abrir o seu próprio negócio?

"Ah, necessidade e uma oportunidade de ter aberto esse negócio."

2) Quais foram as principais dificuldades enfrentadas para abrir 0 negócio?

"A dificuldade foi conseguir capital e a organização, assim, alguém pra administrar, eu não sei mexer com dinheiro e fazer a comida ao mesmo tempo, na época, meu marido, que agora é ex, me ajudava com a parte do dinheiro, porque ele era bom com isso também."

3) Quais os fatores que ajudaram você a vencer as dificuldades de empreender?

"Eu busquei ajuda financeira e peguei dinheiro emprestado no banco, não foi fácil porque eu peguei no nome do meu patrão na época, porque nunca deixei de trabalhar como empregada doméstica, teve até uma época que parei de vender por não estar dando conta dos pedidos, pensei em ficar só vendendo as quentinhas, mas tinha filha pequena e não queria trocar o certo pelo duvidoso, aí voltei a vender, quando vi que o que eu ganhava era muito pouco e estava me divorciando também."

4) Como você conseguiu capital para abrir sua empresa? A entrevistada listou como um dos fatores que a ajudaram a vencer as dificuldades a obtenção de capital.

5) Quais são os principais desafios que você enfrenta hoje na gestão do seu negócio?

"Ah, a concorrência é muito grande, aqui na favela tem muita gente vendendo quentinhas, salgados, porque as pessoas deixam de comprar roupa, sapato, bolsa, mas comida não."

6) De que forma você busca superar esses desafios? "Ah, eu tenho meu diferencial né? Procuro trabalhar com alimentos diferenciados como comidas mais saudáveis que as pessoas estão procurando mais agora, faço salgados, vendo pastéis, empadão, faço até suco verde."

7) Quais são os fatores que facilitam/favorecem a sua gestão? 
"Eu conto muito com a ajuda da minha família, das minhas irmãs e das minhas filhas. Elas me ajudam com a mão de obra e aí fica mais fácil, porque preparar essa comida toda é cansativo pra fazer sozinha."

8) Você conta com o apoio de alguma inciativa governamental? Em caso afirmativo, qual e de quem?

"Não, já tentei, mas achei complicado demais." 